selection. He asserts, for example, that "The idea of hell-fire is, quite simply, self-perpetuating, because of its own deep psychological impact" (p212), although he does not tell us how its "deep psychological impact" provides a mechanism for its selfperpetuation. He shrugs off without analysis the much more plausible and clearly causal hypothesis that hell-fire is not self-perpetuating, but is perpetuated by some people because it gives them power over other people. In fact, both Dawkins' suggestion that ideas are replicating selected units and the sociologists' notion that the details of human social activity are coded in our genes and selected for maximum reproductive potential, arise from the same fallacious view of human society, which, in turn, is a reflection of their confusion between materialism and reductionism. Although it is true that human beings are material objects whose brains are the

\section{Compendium of physiology}

Introduction to Physiology. Vol. 3. By H. Davson and M. B. Segal. Pp. $x+$ 656. (Academic: London; Grune and Stratton: New York, 1976.) £9.80.

THE appearance of the third volume of this series so shortly after the first two (for review see Nature 259, 428; 1976) is a great tribute to the industry as well as the erudition of the authors. It is a pity, even so, that they have been outpaced by inflation and the cost per page has risen from about $13 p$ to $15 p$.

This third volume is devoted mainly to the homeostatic control of the principal mass-transport systems of the mammal-the circulatory, respiratory, alimentary and urinary systems. There are also sections, in the Bernard tradition, on thermoregulation, the control of plasma electrolytes and blood sugar, and a concluding one on the internal environment of the central nervous system in which the writers are, of course, very much on their home ground. Each of these topics is covered in considerable depth and the bibliography which is appended to each section is copious including virtually all workers who have achieved prominence in their respective fields over the past 20 years as well as many whose contributions are less familiar.

What seems to be emerging is a compendium of contemporary physiology rather than an introduction to the subject. The various sections, although providing detailed and thoughtful surveys of current ideas, suffer somewhat from a lack of contour lines which might help the noviti- result of a developmental process under the influence of genes, it is not true that their minds can be understood when we understand their genes. In like manner, although human society is the product of the sensuous activity of material individuals, human society is not simply the collection of all individuals.

According to Richard Dawkins, "If superior creatures from space ever visit earth, the first question they will ask, in order to assess the level of our civilisation is 'Have they discovered evolution yet?',". I think it more likely they will want to know whether we know the difference between properties of sets and properties of their members.

R. C. Lewontin is Alexander Agassiz Professor of Zoology in the Museum of Comparative Zoology and Professor of Biology at Harvard University, Cambridge, Massachusetts.

ate to distinguish the salient features in the detailed scenario which is presented. The text is complemented by frequent clear and apposite illustrations, although in one instance, at least, the figure contradicts what is written elsewhere and occasional pictures of apparatus hardly merit the space they occupy. In the text itself there are some confusing and inconsistent statements but these are rare and could well result from hasty proofreading. Also from time to time an idea is tantalisingly floated without being adequately developed.

Now that the half-way stage in its production has been reached, the question must arise as to what type of user is likely to gain most from this multivolume treatise. My own impression is that it is too detailed to serve as a working source book for the average medical student who may, however, find it valuable for occasional consultation. On the other hand, Honours undergraduates in most UK universities would probably be encouraged to read original papers rather than rely on summaries, however well prepared. This leaves postgraduate students who, particularly on taught courses, could find their needs well catered for, and finally there is the harassed teacher who may be called on to give lectures or tutorials outside his own speciality. Persons in the last category should be heartily grateful to Drs Davson and Segal for having so diligently 'researched' such a wide range of important topics and having so skilfully blended and packaged the fruits of their labours.

R. V. Coxon

$R$. V. Coxon is Reader in Human Physiology at the University of Oxford, UK.

\section{Isotachophoretic} analysis

Isotachophoresis: Theory, Instrumentation and Applications. (Journal of Chromatography Library, Vol. 6.) By F. M. Everaerts, J. L. Beckers and T. P. E. M. Verheggen. Pp. xiv +418 . (Elsevier Scientific: Amsterdam, Oxford and New York, 1976.) Dfl. 160; $\$ 61.50$.

THIS is an important book. Its senior author, Dr F. M. Everaerts, was introduced to isotachophoresis some twelve years ago by his $\mathrm{PhD}$ supervisor, the legendary A. J. P. Martin. Since then Everaerts and his group have developed the technique from a laboratory curiosity to arguably the most versatile method available for the characterisation and determination of low to medium molecular weight electrolytes. It is a method which in my view is destined to become one of the standard tools of chemical analysis.

Essentially the book is a full report of the work done by Everaerts' group; as such the treatment of the subject is uneven. The theoretical section does not provide a good introduction to the subject. The long chapter describing a mathematical model of isotachophoresis seems out of place and adds little of practical value. The qualitative aspects of isotachophoresis, however, are adequately described and the chapter on ionic mobilities summarises the variables available for exploitation by the analyst.

The section on instrumentation is by far the best. It provides a clear account of the problem of detection and of presently available solutions to it. The descriptions of the apparatus are complete enough for anyone with sufficient skill to build an analyser for himself.

The applications section is the most disappointing of all. In spite of the wealth of experimental data presented, there are no comparisons made with rival, well established techniques. A careful perusal of the separations depicted in (say) Fig. 12.4 (p 303) and Fig 15.1 and 15.2 (pp 350-351) will convince any analyst of the value of the technique.

In spite of its shortcomings this book ought to be read by all analysts of electrolyte solutions. Scientific instrument manufacturers should also find it of considerable interest, and possibly very profitable.

Frank Hampson

Frank Hampson is a Research Fellow in the School of Molecular Sciences, University of Sussex, UK. 